\title{
ATP-Induced Cytoplasmic Calcium Mobilization in Bergmann Glial Cells
}

\author{
S. Kirischuk, ${ }^{1}$ T. Möller, ${ }^{2}$ N. Voitenko, ${ }^{1}$ H. Kettenmann, ${ }^{2}$ and A. Verkhratsky ${ }^{1}$ \\ 'Bogomoletz Institute of Physiology, Kiev-24, GSP 252601, Ukraine and 2Max-Delbrück-Center of Molecular \\ Medicine, 13122 Berlin-Buch, Germany
}

\begin{abstract}
ATP receptor mediated $\mathrm{Ca}^{2+}$ signalling was recorded from Bergmann glial cells in cerebellar slices obtained from mice of different ages (postnatal days 6 to 45). To measure the cytoplasmic concentration of $\mathrm{Ca}^{2+}\left(\left[\mathrm{Ca}^{2+}\right]_{i n}\right)$, either individual cells were loaded with the $\mathrm{Ca}^{2+}$-sensitive probes using the whole cell patch clamp technique or slices were incubated with the dye and the microfluorimetric system was focused on individual cells. Signals were recorded either with single-detector microfluorimetry of the dye fura-2 or by confocal laser scanning microfluorimetry (fluo-3based recordings). Extracellular application of $100 \mu \mathrm{M}$ ATP caused a transient elevation of $\left[\mathrm{Ca}^{2+}\right]_{i n}$, which amplitude was significantly higher in Bergmann glial cell processes as compared with their soma. The rank order of potency for the purinoreceptor agonists was: ADP $\geq$ ATP $>$ UTP $>$ AMP $=$ adenosine $=\alpha, \beta$-methylene-ATP. ATP-triggered $\mathrm{Ca}^{2+}$ transients were reversibly inhibited by the $P_{2}$ purinoreceptor agonist suramin $(100 \mu \mathrm{M})$. The involvement of $P_{2}$ metabotropic receptors is inferred by the observation that ATP mediated cytoplasmic $\mathrm{Ca}^{2+}$ transients were not associated with a measurable change in membrane conductance. The $\left[\mathrm{Ca}^{2+}\right]_{\text {in }}$ increase was due to release from inositol-1,4,5-trisphosphate (Ins $\mathrm{P}_{3}$ )-sensitive intracellular stores since responses were still observed in $\mathrm{Ca}^{2+}$-free extracellular solutions and were irreversibly blocked by the inhibitor of the sarco(endo)plasmic reticulum $\mathrm{Ca}^{2+}$ ATPase, thapsigargin, and by the competitive inhibitior of the Ins $P_{3}$ gated intracellular $\mathrm{Ca}^{2+}$ channels heparin. Intracellular dialysis altered the refilling process of the $\operatorname{Ins} \mathrm{P}_{3}$-sensitive stores, suggesting that cytoplasmic factors control ATPmediated $\mathrm{Ca}^{2+}$ signalling.
\end{abstract}

[Key words: cerebellum, glial cells, confocal microfluorimetry, calcium signalling, purinoreceptors, thapsigargin, Ins $P_{3}$-induced calcium release]

Bergmann glial cells are important elements of the cerebellar cytoarchitecture being in intimate contact with Purkinje neurons and in particular with synaptic structures. While they play a

\footnotetext{
Received Apr. 24, 1995; revised July 7, 1995; accepted July 13, 1995.

This research was supported by Bundesministerium für Forschung und Technologie (H.K.), by Sandoz Gerontological foundation (A.V.), and by Deutsche Forschungsgemeinschaft (Grant UKR 436 to A.V.). We are grateful to Professor Haberkorn, Bayer AG, Leverkusen, Germany, for providing suramin and to Dr S. Wray for helpful suggestions on the manuscript. We thank R. Krauß for excellent technical assistance.

Correspondence should be addressed to H. Kettenmann, Max-Delbrück-Center of Molecular Medicine, Robert-Rössle-Strasse 10, 13122 Berlin-Buch, Germany.

Copyright $\bigcirc 1995$ Society for Neuroscience $0270-6474 / 95 / 157861-11 \$ 05.00 / 0$
}

defined role for the development of the cerebellum by forming a pathway for granule cell migration (Hatten et al., 1990), their function in the adult is not known. Recent experiments indicate that Bergmann glial cells express transmitter receptors that may enable these cells to sense synaptic activity. These receptors include those for the inhibitory neurotransmitter GABA (Müller et al., 1994) and for the excitatory glutamate (Burnashev et al., 1992; Müller et al., 1992). The glutamate-induced response is due to the activation of AMPA/kainate-ionotropic receptors; moreover, NMDA responses have also been detected (Müller et al., 1993). All these receptors are ionotropic thus mediating electrical signalling. The AMPA/kainate receptor provides a pathway for $\mathrm{Ca}^{2+}$ influx, participating thus in the generation of cytoplasmic $\mathrm{Ca}^{2+}$ signals (Burnashev et al., 1992; Müller et al., 1992).

While the presence of ligand-gated channels in Bergmann glial cells is well documented, metabotropic receptors have not been described so far. These receptors could provide an alternative pathway for cytoplasmic $\mathrm{Ca}^{2+}$ signalling in Bcrgmann glial cells. Activation of metabotropic receptors controls the activity of phospholipase C (PLC), which hydrolyses the membrane-bound phospholipid phosphatidylinositol 4,5-biphosphate $\left(\mathrm{PIP}_{2}\right.$ ), forming diacylglycerol (DAG-an activator of proteinkinase $C$ ) and inositol-1,4,5-trisphosphate ( $\left.\operatorname{Ins}_{3}\right)$; InsP $\mathrm{P}_{3}$, in turn, activates $\mathrm{Ca}^{2+}$ release from internal stores (see Ferris and Snyder, 1992; Berridge, 1993, for review). A number of nnelabotropic receptors coupled with $\operatorname{InsP}_{3}$ turnover have been discovered in astrocytes and neurons (Fisher and Agranof, 1987; Kimelberg, 1988).

Recent studies demonstrated that the family of CNS neurotransmitters now includes ATP (Stone, 1981; Burnstock, 1990). ATP was reported to act via two classes of purinoreceptors, namely ionotropic (ATP-gated ionic channels; Bean, 1992; Kettenmann et al., 1993) or metabotropic, coupled with $\mathrm{InsP}_{3}$ turnover and subsequent cytoplasmic $\mathrm{Ca}^{2+}$ release (Harden et al., 1990; Illes and Nörenberg, 1993). While cultured astrocytes and microglial cells possess the ionotropic $\left(\mathrm{P}_{2 \mathrm{X}}\right)$ receptor, the metabotropic $\left(\mathrm{P}_{2 Y / N}\right)$ receptor is present in oligodendrocytes (Magowski and Walz, 1992; Walz et al., 1993; Kirischuk et al., 1994). In the present article, we demonstrate the presence of metabotropic purinoreceptors in Bergmann glial cells; the activation of these receptors by adcninc nuclcotides triggers the generation of a cytoplasmic calcium elevation.

\section{Materials and Methods}

Cerebellar slices preparation

Experiments were performed on cerebellar slices acutely isolated from mice of various age groups (namely, postnatal day 6, 16-20, and 40- 
45). The experimental technique for electrophysiological recordings from cells in cerebellar slices has been described elsewhere (Edwards et al., 1989; Kano et al., 1992; Müller et al., 1992). Briefly, mice were decapitated and $150200 \mu \mathrm{m}$ thick sagittal slices were cut from the cerebellum. Cerebellar slices were transferred to the experimental chamber, mounted on the stage of an upright microscope (Axioscope, Zeiss, Oberkochen, Germany), and continuously superfused with a salt solution. Cells were visualized by a long-distance water-immersion objective (40×, NA 0.75).

\section{Current recording}

Membrane currents and transmembrane potential were recorded using the standard whole-cell patch-clamp technique (Hamill et al., 1981) in the voltage- or current-clamp mode. Seal resistances greater than 10 $\mathrm{G} \Omega$ were oblained using patch pipettes with resistances of 3-5 M $\Omega$ Morphologically identified Bergmann glial cells were approached with patch pipettes under visual control with positive pressure applied to the patch pipette solution; no cleaning of the cell somata was performed prior to the experiment. In all experiments, compensation of the series resistance was performed using the standard procedure of either RK300 (BioLogic, France) or EPC-7 amplifier (List Electronics, Darmstadt, Germany). Current signals were filtered at $3 \mathrm{kHz}$ and sampled at 3-5 $\mathrm{kHz}$ by an interface (TIDA, Battelle, Germany) connected to an ATcompatible computer system, which also served as a stimulus generator.

\section{$\left[\mathrm{Ca}^{2+}\right]_{\text {in }}$ measurement}

We measured $\left[\mathrm{Ca}^{2+}\right]_{\text {in }}$ fluorometrically using either a fura-2-based single-detector technique or fluo-3-based laser confocal scanning microscopy.

Fura-2-based $\left[\mathrm{Ca}^{2+}\right]_{\text {in }}$ measurements. Bergmann glial cells were loaded with fura-2 via either incubation of cerebellar slices with fura-2 acetoxymethylester (bulk loading procedure) or by dialyzing the cell through the patch pipette with a solution containing fura- 2 pentapotassium salt (fura $2 \mathbf{K}_{5}$ ). For bulk loading, cerebellar slices were incubated in a physiological salt solution supplemented with fura-2/AM $(5 \mu \mathrm{M}$, diluted in DMSO) for $20 \mathrm{~min}$ at $35^{\circ} \mathrm{C}$. Subsequently, slices were incubated in physiological solution for an additional $60 \mathrm{~min}$ to ensure fura-2/AM deesterification

For fura-2 excitation, cells were illuminated with two alternating wavelength at $360 \pm 5 \mathrm{~nm}$ and $390 \pm 5 \mathrm{~nm}$. Excitation filters were mounted in a filter wheel set at 5 revolutions per second. The emitted light was collected at $510 \pm 10 \mathrm{~nm}$ by a photomultiplier. Both the filter wheel and photomultiplier output were controlled by the Fura- 2 system (by Luigs and Neumann, Rattingen, Germany). Signals corresponding to both excitation wavelengths were fed to an IBM compatible PC via the TIDA interface. $\left[\mathrm{Ca}^{2+}\right]_{\text {in }}$ values were calculated off line.

To reduce the background fluorescence and select the region of interest, the UV illumination was attenuated by an adjustable diaphragm installed in the light path. The $1 \mathrm{~mm}$ pinhole was inserted in front of the photomultiplier housing such that fluorescence collection was equivalent to a $40 \mu \mathrm{m}$ spot at the object plane. Dye-loaded Bergmann glial cells were positioned in such a way that the fluorescent signal was collected from their soma and proximal dendrites (see Fig. 1). After completion of $\left[\mathrm{Ca}^{z+}\right]_{\text {in }}$ recordings from bulk-loaded cells, they were approached with a patch pipette to measure their resting potential. Only cells with RP more negative than $-65 \mathrm{mV}$ were considered for further analysis. After $10 \mathrm{~min}$ of cell dialysis with dye-free intrapipette solution, the background fluorescence (composed of cell autofluorescence, fluorescence from compartmentalized dye and from neighboring tissue) was determined. These values of background fluorescence were used to correct the $\left[\mathrm{Ca}^{2+}\right]_{\text {in }}$ recordings.

In patch-clamp experiments, background fluorescence at both wavelengths was measured after seal formation in a cell-attached mode and subtracted. After the establishment of the whole-cell mode the loading of the cell with fura-2 took $10-15 \mathrm{~min}$; therefore, we started $\left[\mathrm{Ca}^{2+}\right]_{\text {in }}$ measurements dialyzing the cell for $15 \mathrm{~min}$. The $\left[\mathrm{Ca}^{2+}\right]_{\text {in }}$ was calculated from the ratio $(R)$ of fluorescence recorded at 360 and 390 excitation wavelengths using the equation of Grynkiewicz, Poenie, and Tsien (1985):

$$
\left[\mathrm{Ca}^{2+}\right]_{\text {in }}-K_{d} B\left(R-R_{\min }\right) /\left(R_{\max }-R\right),
$$

where $R_{\min }$ is the fluorescence ratio of $\mathrm{Ca}^{2+}$-free fura- 2 and $R_{\max }$ is the ratio of $\mathrm{Ca}^{2+}$-bound fura-2, while the constant $K_{d} B$ was determined empirically. The system was calibrated in vivo by dialyzing Bergmann cells with various pipette solutions. $R_{\min }$ was measured in cells loaded with (in mM): $\mathrm{KCl} 130$, EGTA 10, fura-2K $\mathrm{K}_{\mathrm{s}} 0.1$, HEPES 50, $\mathrm{pH} 7.3$ (adjusted with $\mathrm{KOH}$ ); $R_{\max }$ was measured in cells loaded with $\mathrm{KCl} 130, \mathrm{CaCl}_{2}$ 10 , fura- $2 \mathrm{~K}_{5} 0.1$, HEPES $50, \mathrm{pH}(\mathrm{KOH}) 7.3$. The constant $K_{d} B$ was calculated using $R$ values obtained from cells loaded with (in $\mathrm{mM}$ ) $\mathrm{KCl}$ 50; EGTA 20, $\mathrm{CaCl}_{2} 15$, fura- $2 \mathrm{~K}_{5} 0.1$, HEPES 50, pH 7.4 (with $\mathrm{KOH}$ ); which had a calculated free $\mathrm{Ca}^{2+}$ concentration of $212 \mathrm{~nm}$ at $24^{\circ} \mathrm{C}$. The parameters $K_{d} B, R_{\min }$ and $R_{\max }$ characterizing the system were $3225 \mathrm{nM}$, 0.9 and 9.7 , respectively.

Measurements of spatial $\left.\mathrm{CCa}^{2+}\right]_{\text {in }}$ distribution. For measuring the spatial distribution of $\left[\mathrm{Ca}^{2+}\right]_{\text {in }}$ we have used a confocal laser scanning microscope Sarastro 2000 (Molecular Dynamics, Sunnyvale, CA). The scanner was mounted on an upright microscope (Axioscope FS from Zeiss, Germany) equipped with $40 \times$ water immersion objective; numerical aperture was 0.75 . Optical excitation was at the $488 \mathrm{~nm}$ line of an argon laser. Bergmann glial cells were loaded with the $\left[\mathrm{Ca}^{2+}\right]_{\text {in }}$ probe fluo-3 (Minta et al., 1989) either using a bulk loading procedure (with $5 \mu \mathrm{M}$ of fluo-3/AM; see above) or cell dialysis with $200 \mu \mathrm{M}$ fluo-3 pentapotassium salt containing intrapipette solution. Fluorescence of fluo-3 was measured at an emission wavelength of $530 \pm 15 \mathrm{~nm}$ selected with a narrow bandpass filter. The power of the laser was adjusted to levels between 9 and $10 \mathrm{~mW}$ (the actual energy applied to the cell was less than $1 \mathrm{~mW}$ ) to avoid fluo-3 bleaching. The confocal system was used in the image scan mode; typically the image was constructed from $256 \times 256$ pixels; these images were acquired every $5 \mathrm{sec}$; in some cases $128 \times 128$ pixel resolution was used, so the images could be collected every $2.5 \mathrm{sec}$. At the beginning of each experiment a series of sections of the stained cell was collected in the vertical direction to find an optimal focal plane. Fluo-3 is a one-wavelength $\mathrm{Ca}^{2+}$-sensitive dye (i.e., there is no spectral shift upon calcium binding) and therefore fluorescence data could not be accurately calibrated as absolute values of $\left[\mathrm{Ca}^{2+}\right]_{\text {in }}$. In order to obtain the fluorescence intensity ratio, the resting fluorescence value was determined at the bcginning of each experiment. This resting fluorescence was obtained by averaging 10 images. All images obtained during the experiment were divided by the average resting fluorescence values. Subcellular topology of $\mathrm{Ca}^{2+}$-dependent fluo-3 fluorescence could be analyzed by selecting regions from the stored images and the pixels in these regions were averaged and extrapolated to continuous traces. For constructing images of Lucifer yellow-loaded cells, fluorescence was excited at $457 \mathrm{~nm}$ and recorded at wavelength $530 \pm 15 \mathrm{~nm}$ selected with an appropriate bandpass filter Acquisition of the fluorescence data and image analysis was performed using the software provided by Molecular Dynamics for the Silicon Graphics workstation. To analyze the fluorescent signals, a series of programs for IBM PC connected with the Silicon Graphics workstation were developed (S.K.).

\section{Solutions and reagents}

The physiological salt solution contained (in $\mathrm{mm}$ ): $\mathrm{NaCl} 135 ; \mathrm{KCl} 5.4$; $\mathrm{CaCl}_{2} 2.5 ; \mathrm{MgCl}_{2} 1 ; \mathrm{NaHCO}_{3} 25, \mathrm{NaH}_{2} \mathrm{PO}_{4} 1.6 ;$ glucose $10 ; \mathrm{pH} 7.4$, when continuously gassed by $5 \% \mathrm{CO}_{2}+95 \% \mathrm{O}_{2}$. To obtain calciumfree solution, $\mathrm{CaCl}_{2}$ was omitted, $\mathrm{MgCl}_{2}$ was increased to $2 \mathrm{~mm}$, and $0.5 \mathrm{~mm}$ EGTA was added, yielding an estimated $\mathrm{Ca}^{2+}$ concentration of about $30 \mathrm{nM}$. The intrapipette solution was (in $\mathrm{mM}$ ): $\mathrm{KCl} 130 ; \mathrm{MgCl}_{2}$ 1.1; fura- $2 \mathrm{~K}_{5} 0.1$ (or fluo-3K $\mathrm{K}_{5} 0.2$ ); HEPES/KOH 10; $\mathrm{pH}$ 7.4. Fura- $2 \mathrm{~K}_{5}$, Fluo- $3 \mathrm{~K}_{5}$, Fura-2/AM, and Fluo-3/AM were obtained from Molecular Probes, Eugene, OR, suramin was the generous gift from Prof. Habercorn, Bayer AG, Leverkusen, Germany, and all other chemicals were from Sigma Chemical Co. (St. Louis, MO).

\section{Results}

\section{Identification of Bergmann glial cells and experimental paradigm}

Bergmann glial cells in cerebellar slices could be easily identified based on their characteristic morphology (small cell bodies, approximately $10 \mu \mathrm{m}$ in diameter, and several processes terminating at the pia) and their location in the Purkinje cell layer. Figure 1 illustrates that morphological appearance; an individual Bergmann glial cell and, for comparison, a Purkinje cell were consecutively injected with the fluorescent dye Lucifer Yellow via a patch pipette. The image was obtained with a confocal microscope. We used two approaches to study $\mathrm{Ca}^{2+}$ transients in Bergmann glial cells: 
A

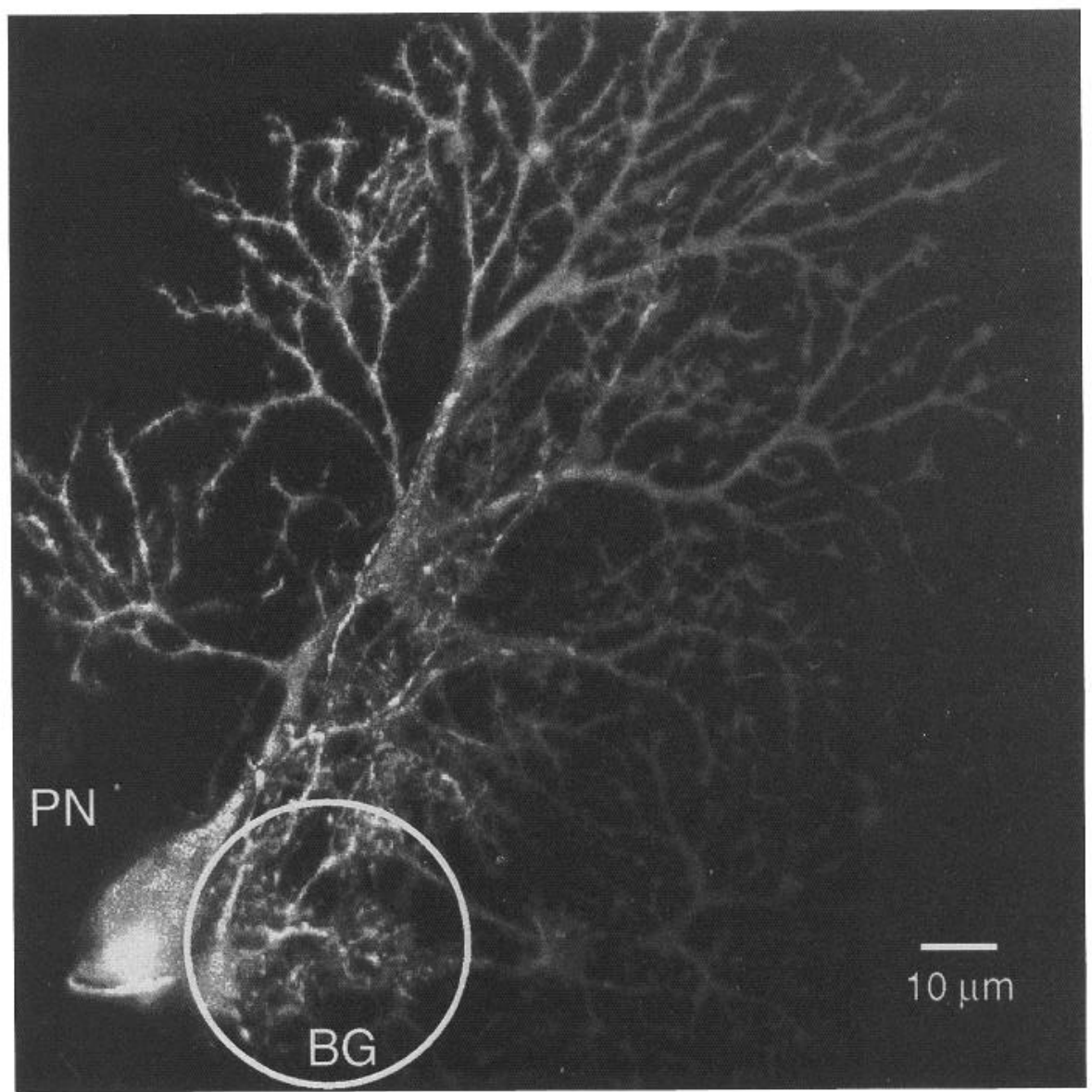

B
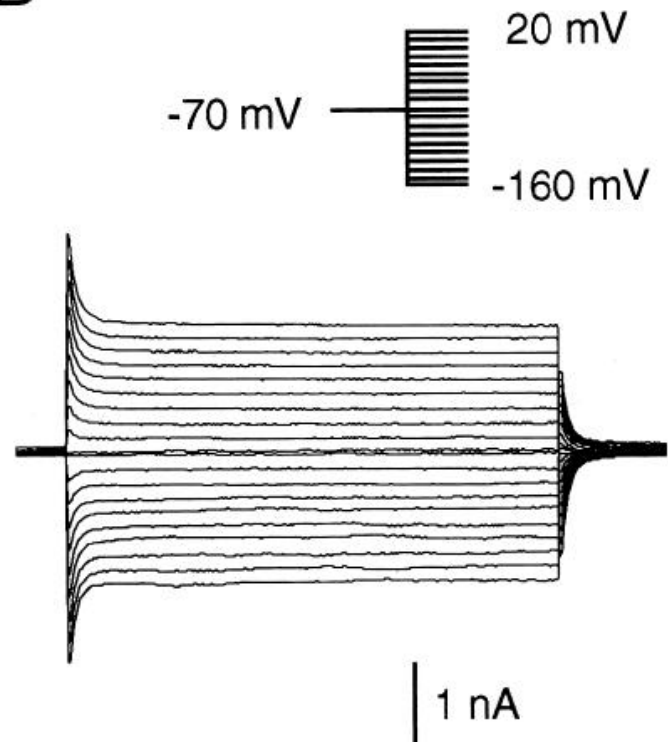

$10 \mathrm{~ms}$
Figure 1. Bergmann glial cell and Purkinje neuron in a mouse cerebellar slice. $A$, The $3 \mathrm{D}$ reconstruction of a pair of neighboring Purkinje neurone $(P N)$ and Bergmann glial cell $(B G)$ loaded by Lucifer yellow via patch pipettes. The circle shows an approximate position of the emitted light collection for $\left[\mathrm{Ca}^{2+}\right]_{\text {in }}$ measurements using fura-2-based single-detector microfluorometry. The cerebellar slice was obtained from a 16-d-old mouse. $B$, Transmembrane ionic currents recorded from the Bergmann glial cell shown in $A$ in response to de- and hyperpolarizing voltage pulses (the voltage protocol is shown in inset). 
Figure 2. ATP-induced $\mathrm{Ca}^{2+}$ elevation and dependence on resting $\left[\mathrm{Ca}^{2+}\right]_{\text {in }} . A$, Examples of ATP-mediated $\left[\mathrm{Ca}^{2+}\right]_{\text {in }}$ transients recorded from three fura-2/AM bulk-loaded Bergmann glial cells. ATP $(100 \mu \mathrm{M})$ was applied as indicated by bars. The resting membrane potential determined after the $\left[\mathrm{Ca}^{2+}\right]_{\text {in }}$ measurements by means of whole-cell current clamp was $-68 \mathrm{mV},-77 \mathrm{mV}$, and $-70 \mathrm{mV}$ (respective for the responses from left to right). $B,\left[\mathrm{Ca}^{2+}\right]_{\text {in }}$ transients in response to increasing concentrations of ATP measured from two different fura-2/AM bulk-loaded Bergmann glial cells with different levels of basal $\left[\mathrm{Ca}^{2+}\right]_{\text {in }}$ concentration. $C$, The peak values of ATP-induced (100 $\mu \mathrm{M})\left[\mathrm{Ca}^{2+}\right]_{\text {in }}$ transients measured from 112 fura-2/AM bulk loaded Bergmann glial cells (filled circles) and resting $\left[\mathrm{Ca}^{2+}\right]_{\text {in }}$ (open circles) are plotted against the corresponding resting $\left[\mathrm{Ca}^{2+}\right]_{\text {in }}$ level. D, ATP-induced $\left[\mathrm{Ca}^{2+}\right]_{i}$ responses evoked at different levels of $\left[\mathrm{Ca}^{2+}\right]_{\text {in }} .\left[\mathrm{Ca}^{2+}\right]_{\text {in }}$ transients evoked by ATP $(100 \mu \mathrm{M})$ were recorded from fura-2/AM bulk-loaded Bergmann glial cell in control conditions and during the recovery phase of a kainate $(100$ $\mu \mathrm{M})$-triggered $\left[\mathrm{Ca}^{2+}\right]_{\text {in }}$ elevation. $\mathrm{Re}$ cordings were separated by $3 \mathrm{~min}$ intervals as indicated on the graph.
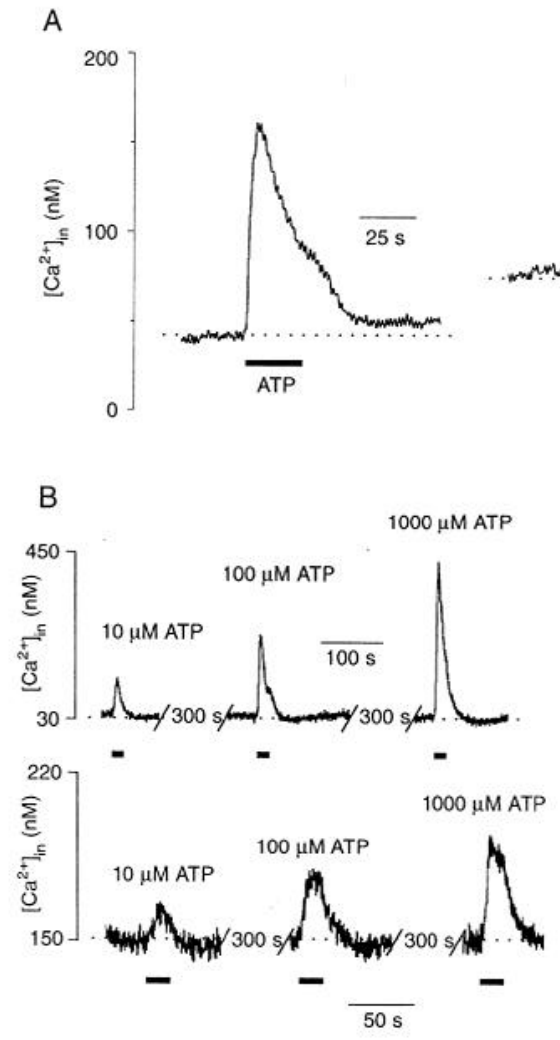

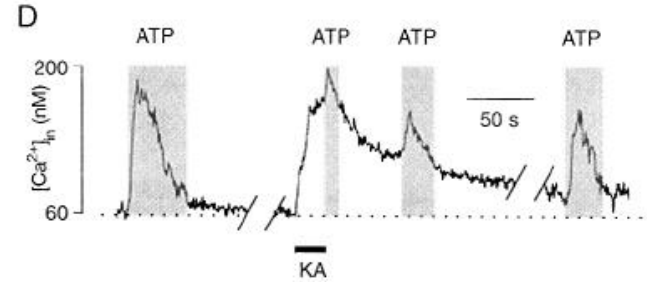

(1) Individual cells were loaded via the patch pipette, and this procedure confined the dye to one single cell. The whole-cell patch-clamp technique allowed us to discriminate Bergmann glial cell from neuronal elements by their distinct electrophysiological characteristics (Fig. 1B). As shown previously, the dominating conductance of the Bergmann glial cell membrane is associated with potassium channels (Müller et al., 1992). To exclude $\mathrm{Ca}^{2+}$ recordings from damaged cells, we used the resting potential (RP) as an indicator of the cell's viability. Only the cells with RP more negative than $-65 \mathrm{mV}$ were considered for further analysis. Among these cells the resting potential averaged at $-73 \pm 6 \mathrm{mV}$ (mean $\pm \mathrm{SD}, n=112$ ).

However, while loading the cell via internal dialysis, one restriction has to be taken into account: since the cell cytoplasm was dialyzed with the patch pipette solution, the intracellular machinery involved in $\left[\mathrm{Ca}^{2+}\right]_{\text {in }}$ homeostasis might be affected.

(2) Bergmann glial cells could also be labeled by incubating the slice with the membrane-permeant forms of $\mathrm{Ca}^{2+}$-sensitive dyes. This was feasible, since Bergmann glial cells accumulated both fura- 2 and fluo-3 considerably faster than the neighboring Purkinje neurons. Thus, by varying the incubation time we preferentially labeled Bergmann glial cells. After completion of the $\left[\mathrm{Ca}^{2+}\right]_{\text {in }}$ measurements the cells were dialyzed with fura-2-free internal solution to (1) measure their RP, and to (2) determine the background fluorescence for correction of $\left[\mathrm{Ca}^{2+}\right]_{\text {in }}$ recordings. Only cells with RP more negative than $-65 \mathrm{mV}$ were considered for further analysis. The resting $\left[\mathrm{Ca}^{2+}\right]_{\text {in }}$ determined in bulk loaded Bergmann glial cells was in the range of 30-200 nM.

\section{ATP triggers $\left[\mathrm{Ca}^{2+}\right]_{\text {in }}$ elevation, but no membrane currents}

ATP $(100 \mu \mathrm{M})$ produced an elevation of $\left[\mathrm{Ca}^{2+}\right]_{\text {in }}$ in the majority of Bergmann glial cells (110 out of 112). The rise in $\left[\mathrm{Ca}^{2+}\right]_{\text {in }}$ reached a peak within $2-4 \mathrm{sec}$ and $\left[\mathrm{Ca}^{2+}\right]_{\text {in }}$ recovered towards the basal level in the continued presence of ATP. Washout of ATP caused a drop in $\left[\mathrm{Ca}^{2+}\right]_{\text {in }}$ to the resting level. Representative examples of ATP-evoked $\left[\mathrm{Ca}^{2+}\right]_{\text {in }}$ transients are shown in Figure $2 A$. The amplitude of ATP-induced $\left[\mathrm{Ca}^{2+}\right]_{\text {in }}$ responses varied between 10 and $250 \mathrm{~nm}$; this amplitude appeared to correlate with the basal $\left[\mathrm{Ca}^{2+}\right]_{\text {in }}$ : at higher basal $\left[\mathrm{Ca}^{2+}\right]_{\text {in }}$, we recorded the smaller amplitudes of ATP-mediated $\left[\mathrm{Ca}^{2+}\right]_{\text {in }}$ responses (Fig. $2 A, D)$.

To study the developmental regulation of the ATP-mediated $\mathrm{Ca}^{2+}$ signalling, we used Bergmann glial cells obtained from mice of three age groups, namely, postnatal day 6, 16-20, and $40-45$. There was no significant difference with respect to the amplitude and shape of ATP-induced $\left[\mathrm{Ca}^{2+}\right]_{\text {in }}$ transients. The action of ATP on $\left[\mathrm{Ca}^{2+}\right]_{\text {in }}$ in Bergmann glial cells appeared to be concentration dependent: examples of $\left[\mathrm{Ca}^{2+}\right]_{\text {in }}$ transients evoked by increasing ATP concentrations are shown in Figure $2 B$. Similarly, as described above, the amplitude of ATP-induced $\left[\mathrm{Ca}^{2+}\right]_{\text {in }}$ transients was strongly modulated by the basal $\left[\mathrm{Ca}^{2+}\right]_{\text {in }}$ level: in cells with resting $\left[\mathrm{Ca}^{2+}\right]_{\text {in }}$ in the range of $30-50 \mathrm{~nm}, 1 \mathrm{~mm}$ of ATP elevated $\left[\mathrm{Ca}^{2+}\right]_{\text {in }}$ to $400-500 \mathrm{nM}$ (Fig. $2 B$, top trace); in cells with basal $\left[\mathrm{Ca}^{2+}\right]_{\text {in }}$ of $150 \mathrm{~nm}$ the response to $1 \mathrm{mM}$ ATP did not exceed $200 \mathrm{~nm}$.

The absolute value for the $\left[\mathrm{Ca}^{2+}\right]_{\text {in }}$ elevation induced by 100 $\mu \mathrm{M}$ ATP peaked at about $150-250 \mathrm{~nm}$. We observed a strong variation in the resting $\mathrm{Ca}^{2+}$ levels among different Bergmann glial cells ranging between 30 to $200 \mathrm{~nm}$. As a consequence, ATP-induced $\mathrm{Ca}^{2+}$ transients from cells with a low basal $\left[\mathrm{Ca}^{2+}\right]_{\text {in }}$ level were larger and varied, while responses of cells with an increased level were smaller. The relationship between the resting $\left[\mathrm{Ca}^{2+}\right]_{\text {in }}$ level and the ATP-induced increase is summarized in Figure $2 C$.

Moreover, under experimentally increased $\left[\mathrm{Ca}^{2+}\right]_{\text {in }}$ levels, the 
A

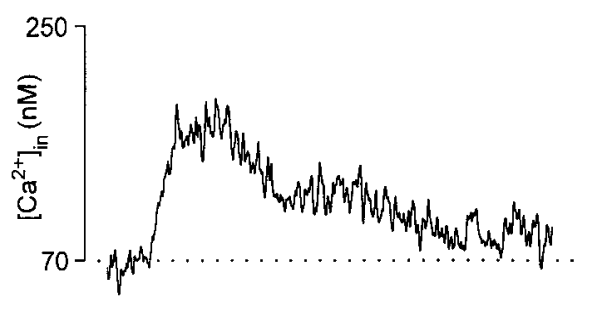

$50 \mathrm{~s}$

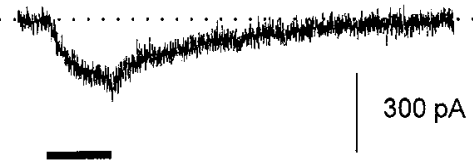

KA
B

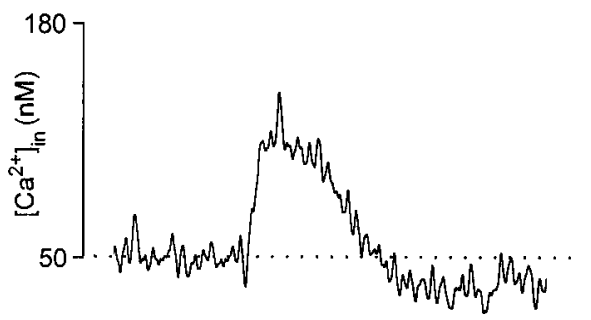

Figure 3. $\left[\mathrm{Ca}^{2+}\right]_{\text {in }}$ transients and transmembrane ionic currents recorded from fura- $2 \mathrm{~K}_{\mathrm{s}}$-loaded Bergmann glial cell in response to stimulation of the ATP-sensitive pathway and glutamate ionotropic receptors. $A$, Extracellular application of kainate $(\mathrm{KA}, 100 \mu \mathrm{M})$ induced the generation of an inward current (bottom) and $\mathrm{a}\left[\mathrm{Ca}^{2+}\right]_{\text {in }}$ elevation (top). $B$, Application of ATP $(100 \mu \mathrm{M})$ generated a $\left[\mathrm{Ca}^{2+}\right]_{\text {in }}$ transient (top) that was not accompanied by measurable changes in the transmembrane ionic current (bottom). The holding potential was $-75 \mathrm{mV}$ throughout the experiment. amplitudes of the ATP responses were strongly attenuated. An example of such an experiment is shown in Figure $2 C$. To experimentally increase $\left[\mathrm{Ca}^{2+}\right]_{\text {in }}$ we used externally applied 100 $\mu \mathrm{M}$ kainate, which is known to induce a transmembrane $\mathrm{Ca}^{2+}$ influx (Müller et al., 1992). After the kainate application and thus during the recovery phase of kainate-triggered $\left[\mathrm{Ca}^{2+}\right]_{\text {in }}$ response, ATP was given at variable intervals. At higher levels of $\left[\mathrm{Ca}^{2+}\right]_{\text {in }}$ the amplitudes of ATP-induced $\left[\mathrm{Ca}^{2+}\right]_{\text {in }}$ transients were smaller.

To test for the presence of ionotropic $\left(\mathrm{P}_{2 \mathrm{X}}\right)$ receptors, we simultaneously recorded membrane currents in the whole-cell recording configuration of the patch-clamp technique. To verify our ability to record ligand-gated membrane currents, we compared ATP responses with those activated by kainate. The latter involves transmembrane $\mathrm{Ca}^{2+}$ influx via ionotropic glutamate receptors of the AMPA/kainate family (Burnashev et al., 1992; Müller et al., 1992). Figure 3 illustrates the simultaneous recording of transmembrane currents and $\left[\mathrm{Ca}^{2+}\right]_{\text {in }}$ obtained from the same Bergmann glial cell in response to $100 \mu \mathrm{M}$ ATP and $100 \mu \mathrm{M}$ kainate. ATP triggers an increase in $\left[\mathrm{Ca}^{2+}\right]_{\text {in }}$ only, whereas kainate generated inward current in concert with a $\left[\mathrm{Ca}^{2+}\right]_{\text {in }}$ transient. Moreover, while recording in the currentclamp mode we never observed a measurable change in the membrane potential upon ATP application.

To test whether the ATP response in the Bergmann glial cell is mediated by indirect effects involving neuronal spiking or the $\mathrm{GABA}_{\mathrm{A}}$ or kainate/AMPA receptors, slices were incubated with the $\mathrm{Na}^{+}$channel blocker tetrodotoxin $(1 \mu \mathrm{M})$, and the receptor antagonists CNQX $(10 \mu \mathrm{M})$ and bicuculline $(1 \mu \mathrm{M})$; as compared to controls, these substances did not influence the ATP-induced $\left[\mathrm{Ca}^{2+}\right]_{\text {in }}$ elevation $(n-9)$.

\section{Subcellular heterogeneity of ATP-induced $\left[\mathrm{Ca}^{2+}\right]_{\text {in }}$ responses}

To investigate the spatial distribution of the ATP-evoked $\left[\mathrm{Ca}^{2+}\right]_{\text {in }}$ responses we used the high-resolution laser scanning confocal microscopy. Cells were loaded with either fluo-3 pentapotassium salt (fluo-3K $\mathrm{K}_{5}$ ) or fluo-3/AM using the bulk-loading procedure, and confocal images of fluo-3 fluorescence were taken every 5 sec. The $\left[\mathrm{Ca}^{2+}\right]_{\text {in }}$ increased much more rapidly and reached high- er levels in distal processes as compared to the soma (Fig. 4). The amplitude of the $\left[\mathrm{Ca}^{2+}\right]_{\text {in }}$ increase was significantly larger in the processes, namely $2.1 \pm 0.8$ times $(n=12)$ as compared to the soma. Figure 4 shows the distribution of $\left[\mathrm{Ca}^{2+}\right]_{\text {in }}$ in a fluo$3 \mathrm{~K}_{5}$-loaded Bergmann glial cell during ATP application.

\section{ATP-induced $\left[\mathrm{Ca}^{2+}\right]_{\text {in }}$ elevation is due to $\mathrm{Ca}^{2+}$ release from Ins $P_{3}$-sensitive internal stores}

As shown above, ATP-induced $\left[\mathrm{Ca}^{2+}\right]_{\text {in }}$ transients were not accompanied by the generation of a detectable membrane current, suggesting that transmembrane $\mathrm{Ca}^{2+}$ influx is not involved in the generation of the ATP-mediated $\left[\mathrm{Ca}^{2+}\right]_{\text {in }}$ response. To substantiate the finding that the $\left[\mathrm{Ca}^{2+}\right]_{\text {in }}$ elevation produced by ATP originates not from transmembrane $\mathrm{Ca}^{2+}$ influx, but from $\mathrm{Ca}^{2+}$ release from internal stores, we compared ATP-mediated $\left[\mathrm{Ca}^{21}\right]_{\text {in }}$ responses in $\mathrm{Ca}^{2+}$-containing versus $\mathrm{Ca}^{2+}$-free extracellular solution. After incubating the slice for $5 \mathrm{~min}$ in a $\mathrm{Ca}^{2+}$-free solution, ATP $(100 \mu \mathrm{M})$ produced a $\left[\mathrm{Ca}^{2+}\right]_{\text {in }}$ elevation similar to the one recorded in normal bathing solution (Fig. $5 A ; n=12$ ). In contrast, $\mathrm{Ca}^{2+}$-free superfusion (for $5 \mathrm{~min}$ ) completely abolished kainate-induced $\left[\mathrm{Ca}^{2+}\right]_{\text {in }}$ responses $(n=9)$, indicating that extracellular $\mathrm{Ca}^{2+}$ in the slice could be lowered to levels preventing influx via plasma membrane pathways.

Prolonged incubation in $\mathrm{Ca}^{2+}$-free solution, however, caused a reduction in the ATP response amplitudes: superfusion of slices with $\mathrm{Ca}^{2+}$-free solution for $15 \mathrm{~min}$ reduced the amplitude of ATP-mediated $\left[\mathrm{Ca}^{2+}\right]_{\text {in }}$ transients to about $20 \%$ of control levels $(n=7)$. This was reversible, since the reintroduction of $\mathrm{Ca}^{2+}$ ions into the external medium completely restored the amplitudes of ATP-triggered $\left[\mathrm{Ca}^{2+}\right]_{\text {in }}$ transients.

To characterize the intracellular pool involved in ATP-triggered $\left[\mathrm{Ca}^{2+}\right]_{\text {in }}$ signalling, we used the tumor promoter thapsigargin, a specific blocker of sarco(endo)plasmic reticulum calcium ATPase (SERCA) pump (Thastrup, 1990; Lytton et al., 1991). Thapsigargin treatment prevented accumulation of $\mathrm{Ca}^{2+}$ ions by intracellular pools, thereby decreasing the amount of releasable calcium. As illustrated in Figure $5 B$, extracellular administration of thapsigargin $(500 \mathrm{nM})$ did not change the resting $\left[\mathrm{Ca}^{2+}\right]_{\text {in }}$. However, $5 \mathrm{~min}$ after thapsigargin application, ATP- 


\section{A}

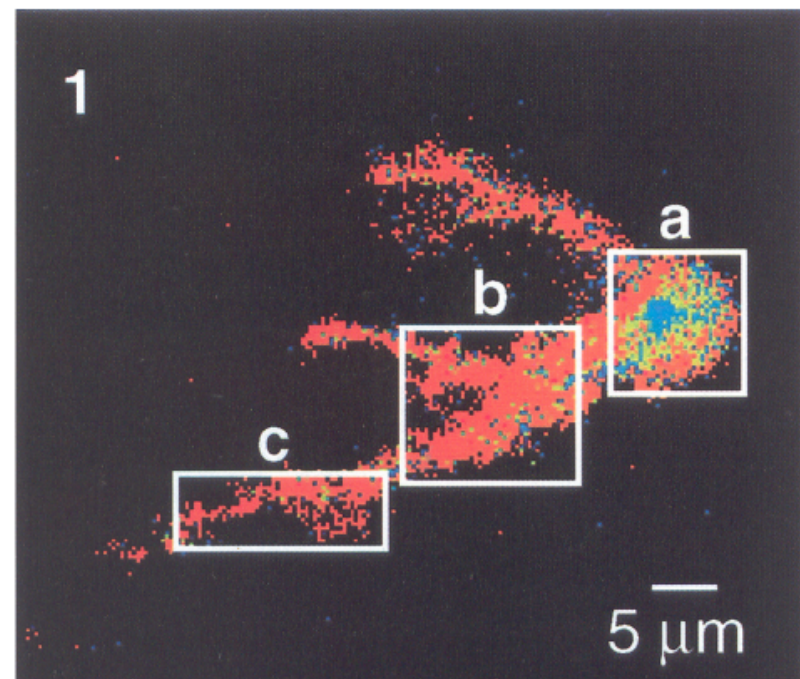

2

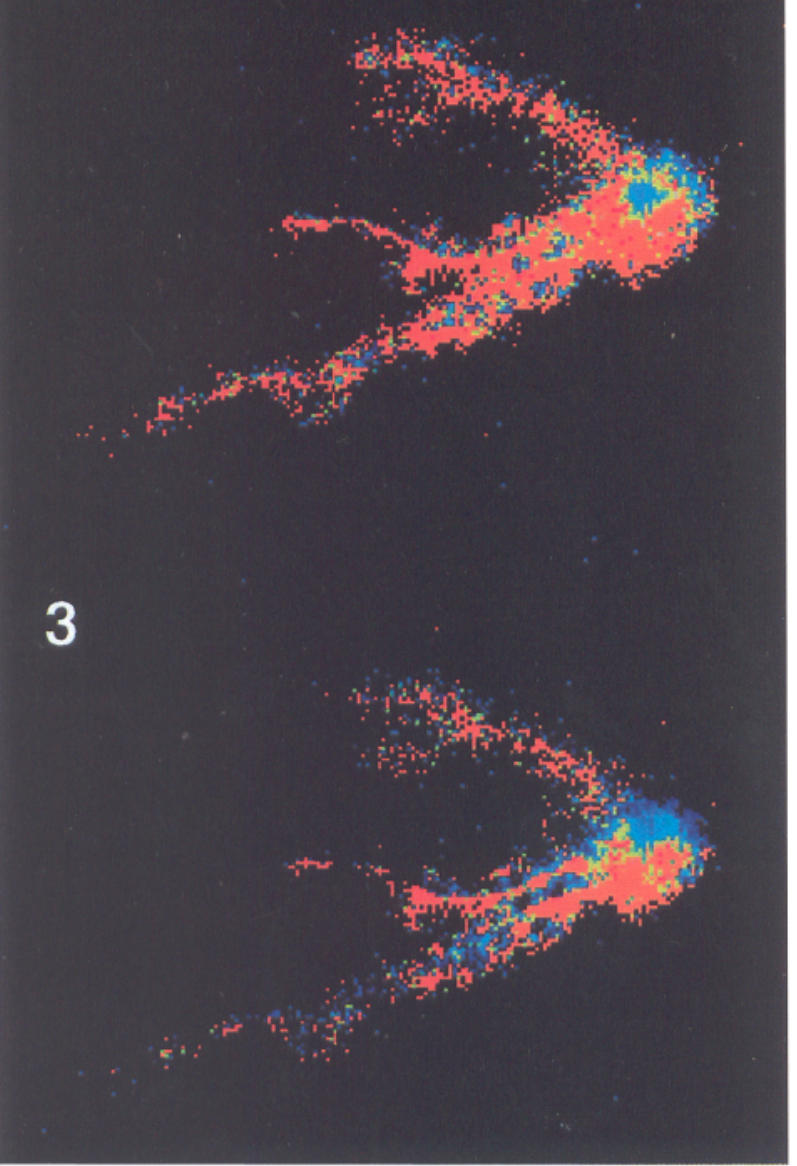

B
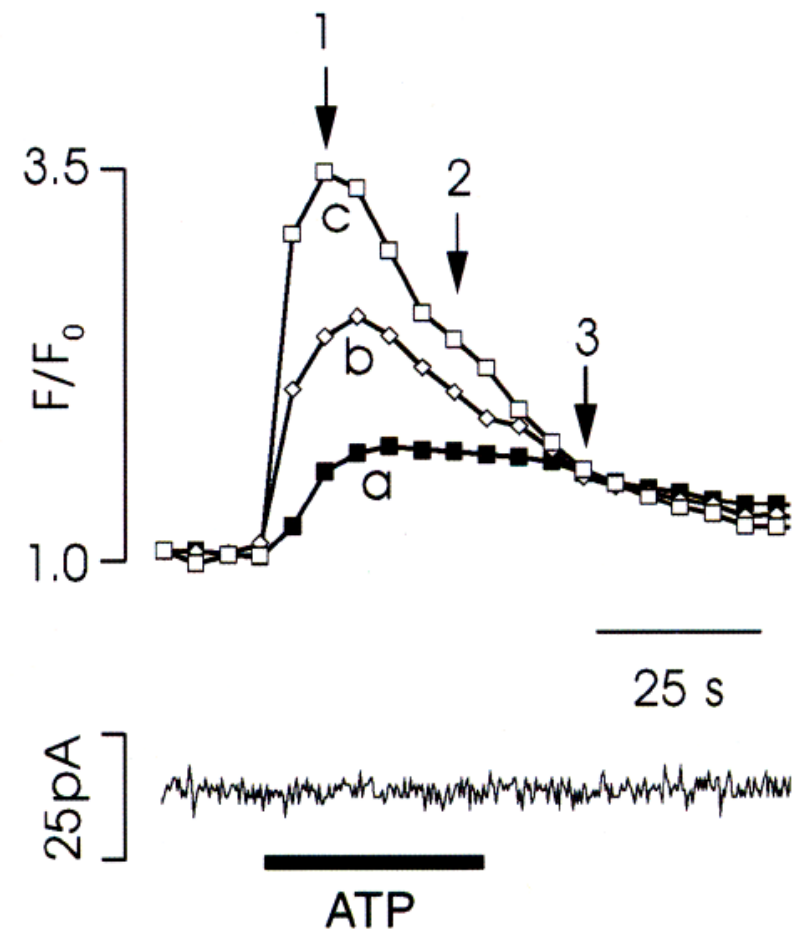

Figure 4. Spatial distribution of the ATP-induced $\left[\mathrm{Ca}^{2+}\right]_{\text {in }}$ signal. A, Pseudocolor images of a fluo-3K $\mathrm{K}_{5}$-loaded Bergmann glial cell during ATP application $(100 \mu \mathrm{M})$. Images were aquired using a laser scanning confocal microscope and then normalized (with pixel by pixel ratioing) to the images taken from the resting state of the cell (see Experimental Procedures). The increases in $\left[\mathrm{Ca}^{2+}\right]_{\text {in }}$ were color coded; low $\left[\mathrm{Ca}^{2+}\right]_{\text {in }}$ levels correspond to blue, high $\left[\mathrm{Ca}^{2+}\right]_{\text {in }}$ levels to red. B, Top: the relative increase of fluo- 3 fluorescence (corresponding to the $\left[\mathrm{Ca}^{2+}\right]_{\text {in }}$ elevation) in response to ATP application $(100 \mu \mathrm{M})$ measured separately from distal $(a)$ and proximal $(b)$ processes and from the soma $(c)$ of the Bergmann glial cell shown in $A$. The selected regions for the measurements are indicated by white boxes in $A$. Images shown in $A$ were taken at points indicated by arrows. Bottom: simultaneous recording of transmembrane current (holding potential $-75 \mathrm{mV}$ ) shows no changes in membrane permeability upon ATP application. 
A
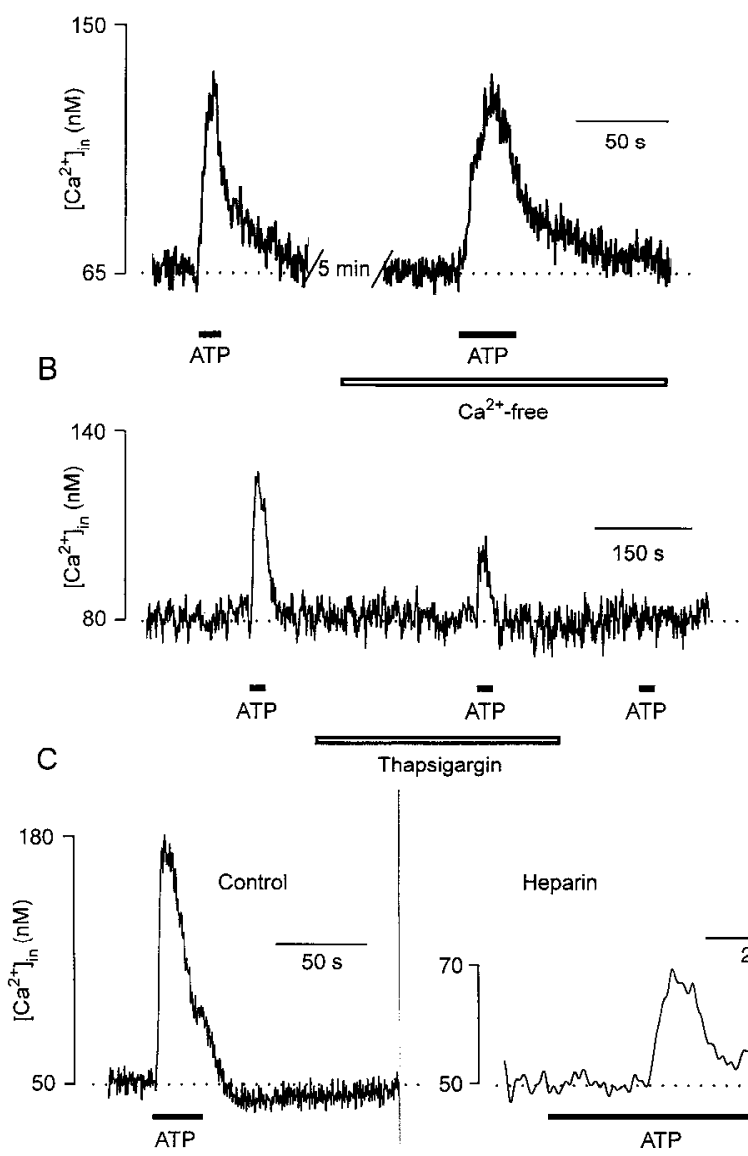

sigargin

Figure 5. ATP induces $\mathrm{Ca}^{2+}$ release from internal stores in Bergmann glial cells. $A$, The $\left[\mathrm{Ca}^{2+}\right]_{\text {in }}$ was recorded from a fura-2/AM bulk- loaded Bergmann glial cell. Applications of ATP $(100 \mu \mathrm{M})$ induced a $\left[\mathrm{Ca}^{2+}\right]_{\text {in }}$ elevation in control conditions and after $5 \mathrm{~min}$ slice superfusion with $\mathrm{Ca}^{2+}$-free, EGTA-containing extracellular solution. The RP of the cell determined after the end of $\left[\mathrm{Ca}^{2+}\right]_{\text {in }}$ recording was $-74 \mathrm{mV}$. B. Thapsigargin inhibits ATP-induced $\left[\mathrm{Ca}^{2+}\right]_{\text {in }}$ transients in a fura-2/AM bulkloaded Bergmann glial cell. The ATP $(100 \mu \mathrm{M})$-induced $\left[\mathrm{Ca}^{2+}\right]_{\text {in }}$ responses are compared in control solution and after slice superfusion with $500 \mathrm{~nm}$ thapsigargin-containing solution. The RP of the cell determined at the end of $\left[\mathrm{Ca}^{2+}\right]_{\text {in }}$ recordings was $-70 \mathrm{mV}$. C, Intracellularly applied heparin $(1 \mu \mathrm{M})$ blocks ATP-induced $\left[\mathrm{Ca}^{2+}\right]_{\text {in }}$ signals in a Bergmann glial cell. The control $\left[\mathrm{Ca}^{2+}\right]_{\text {in }}$ transient was recorded from the fura-2/AM bulk-loaded cell; then the cell was dialyzed with heparincontaining pipette solution and $5 \mathrm{~min}$ later the second record (shown on the right) was taken. The ATP-induced $\left[\mathrm{Ca}^{2+}\right]_{\text {in }}$ transient activated slower and the peak amplitude was considerably smaller.

evoked $\left[\mathrm{Ca}^{2+}\right]_{\text {in }}$ transients were considerably smaller as compared to controls. Moreover, a consecutive application of ATP failed to elicit any changes in $\left[\mathrm{Ca}^{2+}\right]_{\text {in }}$. The action of thapsigargin was almost irreversible: 30 to 45 min washout with control solution restored the amplitude of ATP-induced $\left[\mathrm{Ca}^{2+}\right]_{\text {in }}$ transients to only $10-15 \%$ as compared to the control levels at the beginning of the experiment. Thapsigargin effectively inhibited ATPmediated $\left[\mathrm{Ca}^{2+}\right]_{\text {in }}$ transients in all cells studied $(n=10)$.

To examine the intracellular mechanism responsible for ATPinduced $\left[\mathrm{Ca}^{2+}\right]_{\text {in }}$ signalling we used the specific blocker of $\mathrm{InsP}_{3}$ gated $\mathrm{Ca}^{2+}$ channels of the endoplasmic reticulum, heparin (Hill et al., 1987). As heparin is a membrane impermeant agent, we delivered it by intracellular dialysis via patch pipette. Control responses were measured from fura-2/AM-loaded Bergmann glial cells; then these cells were approached with patch pipette containing intracellular solution supplemented with $100 \mu \mathrm{M}$ fura- 2 pentapotassium salt and $1 \mu \mathrm{M}$ heparin. Five minutes of internal dialysis with heparin strongly reduced the amplitude (in heparin treated cells the amplitude of ATP-induced $\left[\mathrm{Ca}^{2+}\right]_{\text {in }}$ elevation was only $11 \pm 3 \%(n=7)$ of the control) and attenuated the rising phase of the ATP-mediated $\left[\mathrm{Ca}^{2+}\right]_{\text {in }}$ signal. In contrast, 5 min of internal dialysis with heparin-free intrapipette solution reduced the amplitude of ATP-evoked $\mathrm{Ca}^{2+}$ transient to only 93 $\pm 3 \%$ of the control (Fig. $5 C, n=8$ ).

\section{Refilling of ATP-sensitive internal $\mathrm{Ca}^{2+}$ stores is metabolically dependent}

To test for the ability of the intracellular $\mathrm{Ca}^{2+}$ pool for repetitive signalling, ATP was applied twice separated by a $60 \mathrm{sec}$ interval. As shown in Figure 6A, the second ATP application induced a smaller $\mathrm{Ca}^{2+}$ signal ( $58 \pm 4 \%$ from the control; $n=6$ ). Further applications separated by $60 \mathrm{sec}$ led to a progressive decrease, and the $\left[\mathrm{Ca}^{2+}\right]_{\text {in }}$ response was abolished after four to six sequential ATP applications. Such a decrease presumably reflects the depletion of intracellular stores. After a recovery period of 10 min, ATP again induced $\mathrm{Ca}^{2+}$ signals comparable to the first control, indicating that the stores were refilled.

This recovery was irreversibly blocked by thapsigargin, suggesting that the SERCA pumps are responsible for the restoration $(n=4)$. Moreover, the recovery process also required the presence of extracellular $\mathrm{Ca}^{2+}$ ions: changing to $\mathrm{Ca}^{2+}$-free bathing solution after a series of successive ATP applications did not allow for the recovery of the ATP-induced $\left[\mathrm{Ca}^{2+}\right]_{\text {in }}$ increase $(n$ $=5$ ).

The intracellular dialysis via the patch pipette also affected the recovery of the ATP-induced $\left[\mathrm{Ca}^{2+}\right]_{\text {in }}$ increase. In dialyzed cells, ATP induced $\left[\mathrm{Ca}^{2+}\right]_{\mathrm{in}}$ elevations not more than two or three times, and even after long recording times a response could no longer be elicited $(n=11)$. Figure $6 B$ shows an example of ATP-induced $\left[\mathrm{Ca}^{2+}\right]_{\text {in }}$ transients measured from an internally dialyzed Bergmann glial cell. It is evident that two successive applications of ATP depleted internal $\mathrm{Ca}^{21}$ stores, and responses could not be elicited even after long recovery times.

\section{Characterization of the type of ATP receptor}

To characterize the type of purinergic receptor linked to the liberation of $\mathrm{Ca}^{2+}$ from internal stores, we tested the effect of different purine and pyrimidine nucleotides that have been described to discriminate between different types of purinergic receptors (O'Connor et al., 1991; Illes and Nörenberg, 1993). Agonists, at a concentration of $100 \mu \mathrm{M}$, were successively tested on one cell separated by $10 \mathrm{~min}$ intervals. For this series of experiments, bulk-loaded cerebellar Bergmann glial cells were tested to avoid a rundown of the response as observed with the patch-clamp experiments. Figure $7 \mathrm{~A}$ shows the result of representative experiments in which the amplitude of the fluorescence signal in response to adenosine, AMP, ADP, ATP, $\alpha, \beta$-methylene ATP (Me-ATP) and UTP were compared. The rank order of potency for the purinoreceptor agonists was: ADP $\geq$ ATP $>$ UTP $>>$ AMP $=$ adenosine $=$ Me-ATP $(n=9)$, thus suggesting the involvement of $\mathrm{P}_{2}$ purinoreceptor subtype (Illes and Nörenberg, 1993).

The involvement of $\mathrm{P}_{2}$ purinoreceptors was further confirmed by the blockade of the ATP-induced response by the selective $P_{2}$ receptors antagonist, suramin (Dunn and Blakeley, 1988). Incubation of cerebellar slices with suramin significantly inhibited 
Figure 6. Recovery of the ATP-induced $\mathrm{Ca}^{2+}$ transients in bulk-loaded and dialyzed Bergmann glial cells. $A$, ATP-induced $\left[\mathrm{Ca}^{2+}\right]_{\text {in }}$ transients recorded from a fura-2/AM bulk-loaded Bergmann glial cell. Subsequent applications of $100 \mu \mathrm{M}$ ATP separated with $50 \mathrm{sec}$ intervals caused a progressive decrease of the amplitude of $\left[\mathrm{Ca}^{2+}\right]_{\text {in }}$ responses, presumabely due to the depletion of internal $\mathrm{Ca}^{2+}$ stores. The amplitude of the ATP-induced $\left[\mathrm{Ca}^{2+}\right]_{\text {in }}$ transient recovered to the control value after $10 \mathrm{~min}$, reflecting the replenishment of the $\mathrm{Ca}^{2+}$ pool. The RP of the cell determined at the end of $\left[\mathrm{Ca}^{2+}\right]_{\text {in }}$ recordings was $-80 \mathrm{mV} . B$, A similar experiment as in $A$ was performed on an internally dialyzed Bergmann glial cell loaded with fura- $2 \mathrm{~K}^{5}$. ATP (100 $\mu M)$ applications caused an irreversible depletion of the internal stores. A simultaneous membrane current recording is shown below the $\left[\mathrm{Ca}^{2+}\right]_{\text {in }}$ trace The holding potential was $-75 \mathrm{mV}$.
A

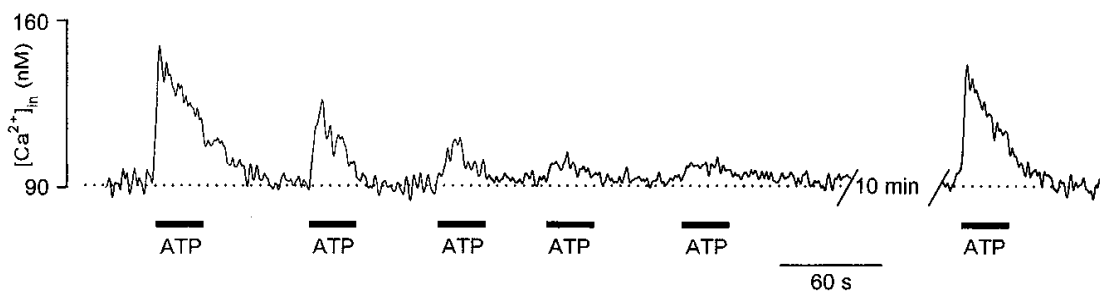

B

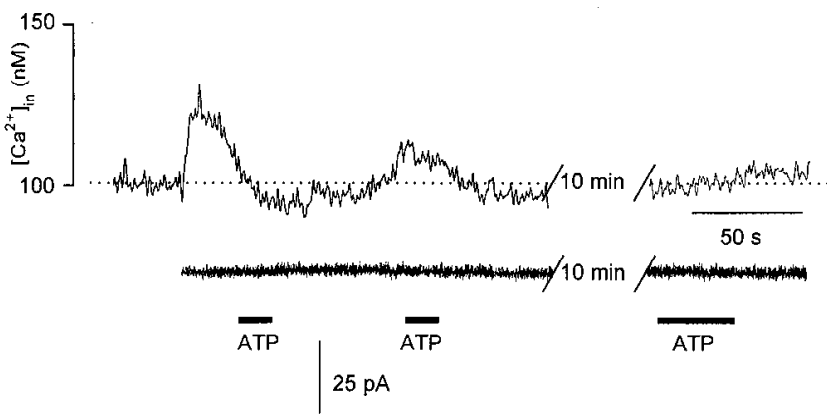

ATP-triggered $\left[\mathrm{Ca}^{2+}\right]_{\text {in }}$ elevation in Bergmann glial cells (Fig. $7 B)$. In the presence of suramin $(100 \mu \mathrm{M}, 30 \mathrm{sec}$ preapplication) the amplitudes of ATP-induced $\left[\mathrm{Ca}^{2+}\right]_{\text {in }}$ responses were $21 \pm$ $7 \%(n=6)$ of the control level. The suramin-induced blockade of the ATP-mediated $\left[\mathrm{Ca}^{2+}\right]_{\text {in }}$ mobilization was reversible: washout with standard bathing solution completely restored $\left[\mathrm{Ca}^{2+}\right]_{\text {in }}$ responses within 10-15 min. In comparison, concentrations of up to $500 \mu \mathrm{M}$ suramin failed to attenuate the kainate-induced $\left[\mathrm{Ca}^{2+}\right]_{\text {in }}$ mobilization ( $n=4$; data not shown).

\section{Discussion}

Bergmann glial cells express $P_{2}$ metabotropic purinergic receptors

In the present study we have demonstrated that ATP increased $\left[\mathrm{Ca}^{2+}\right]_{\text {in }}$ in Bergmann glial cells indicating the presence of ATP receptive sites. ATP is a ligand for a family of purinergic receptors, the $\mathrm{P}_{2}$ receptors. These comprise the $\mathrm{P}_{2 \mathrm{X}}, \mathrm{P}_{2 Z}$, and $\mathrm{P}_{2 \mathrm{~T}}$ receptors coupled with plasmalemmal ionic channels (Bean, 1992) and $\mathrm{P}_{2 \mathrm{U}}$ and $\mathrm{P}_{2 \mathrm{Y}}$ receptors linked to PLC-driven formation of

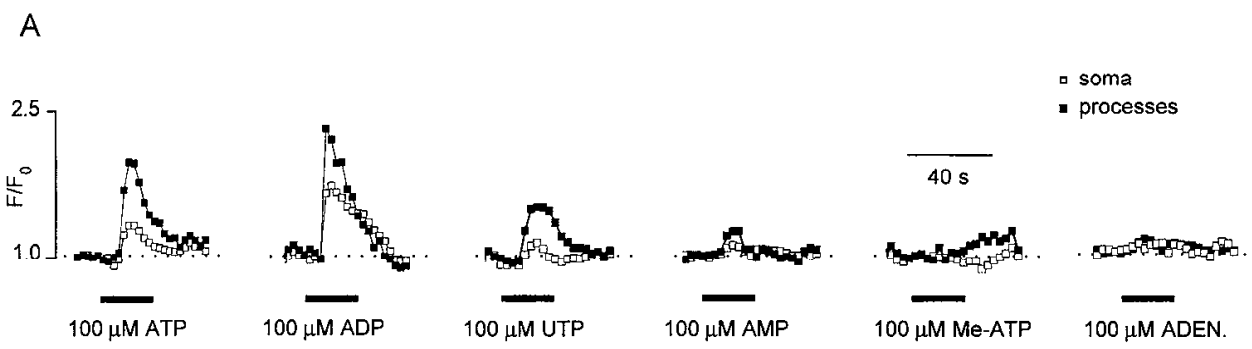

B

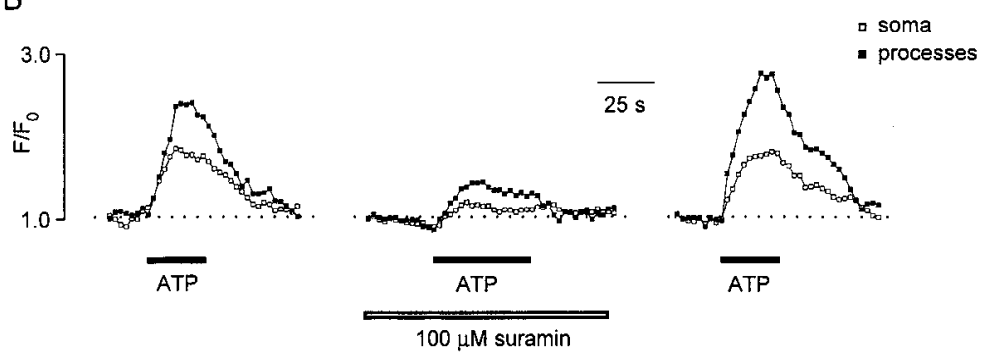

Figure 7. Pharmacological properties of ATP-induced $\left[\mathrm{Ca}^{2}{ }^{1}\right]_{\text {in }}$ responses. $A,\left[\mathrm{Ca}^{2}{ }^{1}\right]_{\text {in }}$ transients were recorded as fluorescence ratio $\left(\mathrm{F} / \mathrm{F}_{0}\right)$ from the fluo-3/AM bulk-loaded Bergmann glial cell in response to application of $100 \mu \mathrm{M}$ adenosine (ADEN), AMP, ADP, ATP, $\alpha, \beta-m e t h y l e n-A T P$ (MeATP), and UTP. Recordings were separated by $10 \mathrm{~min}$ intervals to ensure the refilling of ATP-sensitive $\mathrm{Ca}^{2+} \mathrm{stores}\left[\mathrm{Ca}^{2+}\right]_{\text {in }}$ levels were separately measured at the soma $(a)$ and in the processes $(b)$ of the cell. The RP of the cell determined at the end of $\left[\mathrm{Ca}^{2+}\right]_{\text {in }}$ recordings was $-68 \mathrm{mV}$. $B$, Inhibition of the ATP-induced $\left[\mathrm{Ca}^{2+}\right]_{\text {in }}$ transients by suramin. $\left[\mathrm{Ca}^{2+}\right]_{\text {in }}$ transients (as the fluo-3 fluorescence ratio) were recorded from the soma $(a)$ and processes $(b)$ of the fluo-3/AM bulk-loaded Bergmann glial cell. As a control, $100 \mu \mathrm{M}$ ATP was applied. After 10 min, $100 \mu \mathrm{M}$ ATP was applied in the presence of $100 \mu \mathrm{M}$ suramin. The response was markedly reduced. After a 15 min washout, $100 \mu \mathrm{M}$ ATP induced a similar response as in the control. The RP of the cell determined at the end of $\left[\mathrm{Ca}^{2+}\right]_{\text {in }}$ recordings was $-75 \mathrm{mV}$. 
InsP $_{3}$ (Illes and Nörenberg, 1993). Alternatively, ATP may act through its metabolites AMP and adenosine via activation of $P_{1}$ purinoreceptors.

In the present study on Bergmann glial cells, we demonstrated that the ATP-induced $\left[\mathrm{Ca}^{2+}\right]_{\text {in }}$ elevation was mimicked by ADP and (to certain extents) UTP, but not by AMP or adenosine, suggesting, therfore, the involvement of $\mathrm{P}_{2}$ purinoreceptors. Moreover, the selective blocker of metabotropic $\mathrm{P}_{2}$ receptors, suramin, caused a reversible inhibition of ATP-mediated $\left[\mathrm{Ca}^{2+}\right]_{\text {in }}$ responses. A similar action of suramin on $\mathrm{P}_{2}$-metabotropic receptors-driven $\left[\mathrm{Ca}^{2+}\right]_{\text {in }}$ transients has been found in a number of other systems (Inoue et al., 1991; Kalthof et al., 1993; Salter and Hicks, 1994; Kirischuk et al., 1995). The lack of $P_{2 x}$ receptors is inferred by the observation that (1) the selective agonist of $\mathrm{P}_{2 x}$ receptors, $\alpha, \beta$-methylene-ATP, did not produce a $\left[\mathrm{Ca}^{2+}\right]_{\text {in }}$ elevation and (2) that ATP did not activate membrane currents as expected after $P_{2 X}$ receptor activation. We thus conclude that Bergmann glial cells express $\mathrm{P}_{2}$ metabotropic purinergic receptors.

\section{ATP causes $\mathrm{Ca}^{2+}$ release from Ins $P_{3}$-sensitive internal pools}

Activation of metabotropic $\mathrm{P}_{2}$ purinoreceptors is commonly linked to $\mathrm{Ca}^{2+}$ release from cytoplasmic pools (Harden et al., 1990; O'Connor et al., 1991). This is in line with our observations that (1) the ATP-induced signal can still be recorded in the absence of extracellular $\mathrm{Ca}^{2+}$, suggesting the involvement of intracellular calcium release; and that (2) we did not observe an ATP activated ionic current across the plasma membrane.

Based on the observation that intracellular administration of heparin antagonized the effects of $\Lambda T P$ on $\left[\mathrm{Ca}^{2+}\right]_{\text {in }}$, we can conclude that ATP action is mediated by the intracellular secondmessenger InsP $\mathrm{P}_{3}$ and involves the activation of $\left[\mathrm{Ca}^{2+}\right]_{\text {in }}$ release from an $\mathrm{InsP}_{3}$-sensitive calcium pool.

Fura-2 was reported to act as a competitive inhibitor of Ins $\mathrm{P}_{3}$ binding to its receptor with a $K_{d}$ of $\sim 120 \mu \mathrm{M}$ (Richardson and Taylor, 1993). The estimated cytoplasmic fura-2 concentration in our experiments on bulk-loaded Bergmann glial cells was in the range of 50-60 $\mu \mathrm{M}$, while in patch-clamp experiments we used intracellular solutions supplemented with $100 \mu \mathrm{M}$ fura- 2 . Thus, our experiments were performed in a fura- 2 concentration range in which the inhibitory action of fura- 2 on $\operatorname{InsP}_{3}$-gated $\mathrm{Ca}^{2+}$ channel might lead to an underestimation of the amplitudes of ATP-triggered $\left[\mathrm{Ca}^{2+}\right]_{\text {in }}$ transients. This may also explain why the $\mathrm{EC}_{50}$ of the ATP dose-response curve was unusually high for $\mathrm{P}_{2}$ purinoreceptors (see Fig. $2 B$ ).

The intracellular $\mathrm{Ca}^{2+}$ pool responsible for the $\mathrm{InsP}_{3}$-mediated calcium release accumulates $\mathrm{Ca}^{2+}$ by the activity of the SERCA pumps. Several ATP challenges applied within short time intervals almost completely depleted internal $\mathrm{Ca}^{2+}$ stores; however, within $10 \mathrm{~min}$, the pool of releasable $\mathrm{Ca}^{2+}$ was restored. Blocking the SERCA pump with the specific blocker thapsigargin (Thastrup, 1990) did not prevent a first ATP-induced release, but subsequent ATP applications did no longer elicit a $\mathrm{Ca}^{2+}$ signal, since the $\mathrm{Ca}^{2+}$ gradient could no longer be restored. This inhibition was almost irreversible: ATP responses recovered only partially during 30-45 min after thapsigargin removal. These findings are consistent with the previously reported irreversibility of the thapsigargin-induced blockade of SERCA pumps, presumably via covalent modification (Lytton et al., 1991). Dialyzing the cell interior with the patch pipette impaired the ability of restoring the $\mathrm{Ca}^{2+}$ pools. This suggests that intracellular per- fusion removes critical (yet unkmown) factors controlling $\mathrm{Ca}^{2+}$ uptake into intracellular $\mathrm{Ca}^{2+}$ pools.

\section{$\left[\mathrm{Ca}^{2+}\right]_{\text {in }}$ homeostasis and ATP-induced $\mathrm{Ca}^{2+}$ signalling in Bergmann glial cells}

In previous studies on nonexcitable cells outside the CNS, the blockade of the SERCA pump by thapsigargin produced a significant elevation in $\left[\mathrm{Ca}^{2+}\right]_{\text {in }}$ (see Petersen et al., 1994 for review); in Bergmann glial cells resting $\left[\mathrm{Ca}^{2+}\right]_{\text {in }}$ levels were not affected. This discrepancy might be due to a different interplay between the various $\left[\mathrm{Ca}^{2+}\right]_{\text {in }}$ homeostasis mechanisms: the resting $\left[\mathrm{Ca}^{2+}\right]_{\text {in }}$ levels are determined by a competition between $\mathrm{Ca}^{2+}$ leakage (from internal stores and the extracellular space), the efficiency of the $\mathrm{Ca}^{2+}$ buffer systems, and by the activity of the $\mathrm{Ca}^{2+}$ pumps (transferring $\mathrm{Ca}^{2+}$ ions into internal pools or to the extracellular compartment). The absence of thapsigargin-induced $\left[\mathrm{Ca}^{2+}\right]_{\text {in }}$ elevation in the Bergmann glial cells makes it likely that the levels of $\left[\mathrm{Ca}^{2+}\right]_{\text {in }}$ are strongly controlled by mechanisms other than SERCA pumping, such as highly efficient cytosolic $\mathrm{Ca}^{2+}$ buffer mechanisms, $\mathrm{Ca}^{2+}$ uptake into mitochondria or $\mathrm{Ca}^{2+}$ extrusion into the extracellular space. The importance of the latter mechanism is inferred by the observation that prolonged exposure of cerebellar slices in $\mathrm{Ca}^{2+}$-free solution markedly depressed ATP-mediated $\left[\mathrm{Ca}^{2+}\right]_{\text {in }}$ responses. These observations indicate that $\mathrm{Ca}^{2+}$ extrusion from the Bergmann cell dominates over the $\mathrm{Ca}^{2+}$ turnover between the cytoplasm and internal pools; the latter might be depleted by removal of extracellular calcium. This may also suggest the involvement of transmembrane $\mathrm{Ca}^{2+}$ transport in supplying stores with releasable $\mathrm{Ca}^{2+}$ ("capacitative $\mathrm{Ca}^{2+}$ entry;" Penner et al., 1993; Fasolato et al., 1994).

We found a significant variation in resting $\left[\mathrm{Ca}^{2+}\right]_{\text {in }}$ levels among the individual Bergmann glial cells. It is conceivable that elevated $\left[\mathrm{Ca}^{2+}\right]_{\text {in }}$ might indicate cell damage; however, this seems to be unlikely due to the fact that we analyzed $\left[\mathrm{Ca}^{2+}\right]_{\text {in }}$ signals only in cells with high resting potential (RP more negative than $-65 \mathrm{mV}$ ). We found that the amplitudes of ATPinduced $\left[\mathrm{Ca}^{2+}\right]_{\text {in }}$ responses of Bergmann glial cells appeared to be controlled by the resting $\left[\mathrm{Ca}^{2+}\right]_{\text {in }}$ level: in cells that possessed higher resting $\left[\mathrm{Ca}^{2+}\right]_{\text {in }}$, the amplitudes of the ATP-mediated responses were usually smaller. If the $\left[\mathrm{Ca}^{2+}\right]_{\text {in }}$ levels exceeded 170-180 nM, ATP was almost unable to elevate $\left[\mathrm{Ca}^{2+}\right]_{\text {in }}$ even when applied in high doses. The mechanisms controlling this ceiling concentration remain unresolved. One possibility would be that $\mathrm{Ca}^{2+}$ ions serve as coagonists of $\mathrm{InsP}_{3}$-gated $\mathrm{Ca}^{2+}$ release channels, stimulating them at low and moderate concentrations and inhibiting at high concentrations as described for $\operatorname{Ins}_{3}$-gated channels derived from endoplasmic reticulum of cerebellar neurons (Bezprozvanny et al., 1991). However, $\mathrm{Ca}^{2+}$ ions block Ins $\mathrm{P}_{3}$-gated channels in a micromolar range, whereas we have seen inhibition of ATP-induced responses at $\left[\mathrm{Ca}^{2+}\right]_{\text {in }}$ in a range of $150-200 \mathrm{~nm}$. It is even likely that the resting $\left[\mathrm{Ca}^{2+}\right]_{\text {in }}$ levels may control the responsiveness of the entire ATP-sensitive $\left[\mathrm{Ca}^{2+}\right]_{\text {in }}$ signalling machinery; interaction with any component of this pathway (including purinoreceptors, $\mathrm{Ca}^{2+}$-release channels, SERCA pumps, etc.) may be responsible for the observed phenomena.

\section{Physiological relevance of ATP-mediated $\left[\mathrm{Ca}^{2+}\right]_{\text {in }}$ signals in Bergmann glial cells}

The role of ATP in intracellular metabolism is well established; however, in addition, ATP plays an important role as an inter- 
ccllular signalling molecule. It has been shown that $\Lambda \mathrm{TP}$ acts as an excitatory chemical mediator in both the PNS and CNS (Burnstock, 1990; El-Moatassim et al., 1992). ATP-mediated excitatory synaptic transmission was found in neuromuscular junctions (Benham, 1989) in neuron-neuron synapses in coeliac ganglion (Evans et al., 1992), dorsal horn (Salter et al., 1993), and in the medial habenula (Edwards et al., 1992). In addition, ATP was found to increase $\left[\mathrm{Ca}^{2+}\right]_{\text {in }}$ in a variety of excitable and nonexcitable cells including osteoblasts and osteoclasts (Reimer and Dixon, 1992; Yu and Ferrier, 1993), cultured renal cells (Cejka et al., 1993), smooth muscle cells (Droogmans et al., 1991; Carter and Ogden, 1992; Kalthof et al., 1993), and dorsal horn neurons and astrocytes (Salter and Hicks, 1994).

ATP can be released alone or coreleased with other neurotransmitters from synaptic vesicles (Sawynok et al., 1993), and in addition, it could be liberated from neurites during electrical activity (Maire et al., 1982). In different types of glial cells ATP was found to be the most reliable and widespread agent, which induces cytoplasmic $\mathrm{Ca}^{2+}$ mobilization (see Finkbeiner, 1993; Kastritsis and McCarthy, 1993; Kirischuk et al., 1995). In Bergmann glial cells we have demonstrated that ATP induced a cytoplasmic $\mathrm{Ca}^{2+}$ signal with distinct spatial organization: the ATP-mediated $\left[\mathrm{Ca}^{2+}\right]_{\mathrm{in}}$ responses are higher in Bergmann glial processes versus the soma. This subcellular heterogeneity could be functionally important, taking into account the intimate interaction of the Bergmann glial processes with the Purkinje neuron's dendritic tree. We can speculate that ATP released from synaptic endings of parallel and climbing fibers, which innervate Purkinje neurons, may generate $\left[\mathrm{Ca}^{2+}\right]_{\text {in }}$ signals in Bergmann glial cells. This signal may trigger or regulate several unknown cytoplasmic events or participate in the regulation of interstitial $\mathrm{Ca}^{2+}$ levels. It is known that neuronal activity may induce a significant drop of extracellular calcium: it was demonstrated that during electrical stimulation of hippocampal slices $\left[\mathrm{Ca}^{2+}\right]_{0}$ fell from 2 to $1.4 \mathrm{mM}$ (Benninger et al., 1980); and spreading depression caused $\left[\mathrm{Ca}^{2+}\right]_{0}$ to fall from 2.2 to $0.8 \mathrm{mM}$ (Kraig and Nicholson, 1978). One possible function of Bergmann glial cells may be to serve as dynamic $\mathrm{Ca}^{2+}$ pools during intense synaptic activity by releasing $\mathrm{Ca}^{2+}$ from their internal stores into the extracellular compartment involving purinergic receptor activation, cytoplasmic $\mathrm{Ca}^{2+}$ increase, and $\mathrm{Ca}^{2+}$ extrusion.

\section{References}

Bcan BP (1992) Pharmacology and electrophysiology of ATP-activated ion channels. Trends Pharmacol Sci 13:87-90.

Benham CD (1989) ATP-activated channels gate calcium entry in single smooth muscle cells dissociated from rabbit ear artery. J Pliysiol (Lond) 419:686-701.

Benninger C, Kadis J, Prince DA (1980) Extracellular calcium and potassium changes in hippocampal slices. Brain Res 187:165-182.

Berridge MJ (1993) Inositol trisphosphate and calcium signalling. Nature 361:315-325.

Bezprozvanny I, Watras J, Ehrlich BE (1991) Bell-shaped calciumresponse curves of Ins $(1,4,5) \mathrm{P}_{3}$ and calcium-gated channels from endoplasmic reticulum of cerebellum. Nature 351:751-754.

Burnashev N, Khodorova A, Jonas P, Helm PJ, Wisden W, Monyer H, Seeburg PH, Sakmann B (1992) Calcium-permeable AMPA-kainate receptors in fusiform cerebellar glial cells. Science 256:1566-1570.

Burnstock G (1990) Overview: Purinergic mechanisms. Ann NY Acad Sci 603:1-17.

Carter 'ID, Ogden D (1992) Kinetics of intracellular calcium release by inositol 1,4,5 trisphosphate and extracellular ATP in porcine cultured aortic endothelial cells. Proc R Soc Lond [Biol] 250:235-241.

Cejka JC, Bidet M, Tauc M, Poujeol P (1993) Nucleotides mobilize intracellular calcium stores of renal proximal cells in primary culture: existence of a suramin-sensitive mechanisms. Biochim Biophys Acta Mol Cell Res 1176:7-12.

Droogmans G, Callewaert G, Declerk I, Casteels R (1991) ATP-induced $\mathrm{Ca}^{2+}$ release and $\mathrm{Cl}^{-}$current in cultured smooth muscle cells from pig aorta. J Physiol (Lond) 440:623-634.

Dunn PM, Blakeley AGH (1988) Suramin: a reversible $\mathrm{P}_{2}$-purinoreceptor antagonist in the mouse vas deferens. Br J Pharmacol 93:243245.

Edwards FA, Gibb AJ, Colquhoun D (1992) ATP receptor-mediated synaptic currents in the central nervous system. Nature 359:144-147.

El-Moatassim C, Dornand J, Mani J-C (1992) Extracellular ATP and cell signalling. Biochim Biophys Acta Mol Cell Res 1134:31-45.

Evans RJ, Derkch V, Suprenatant A (1992) ATP mediates fast synaptic transmission in mammalian neurons. Nature 357:503-505.

Fasolato C., Innocenti B, Pozzan T (1994) Receptor-activated $\mathrm{Ca}^{2+}$ influx: how many mechanisms for how many channels? Trends Neurosci $15: 77-83$.

Ferris CD, Snyder SH (1992) Inositol phosphate receptors and calcium disposition in the brain. J Neurosci 12:1567-1574.

Finkbeiner SM (1993) Glial calcium. Glia 9:83-104.

Fisher SK, Agranof BW (1987) Receptor activation and inositol lipid hydrolysis in neuronal tissues. J Neurochem 48:999-1017.

Grynkiewicz G, Poenie M, Tsien RY (1985) A new generation of $\mathrm{Ca}^{2+}$ indicators with greatly improved fluorescent properties. J Biol Chem 260:3440-3450.

Hamill OP, Marty A, Neher E, Sakmann B, Sigworth FJ (1981) Improved patch clamp techniques for high-resolution current recording from cell and cell-free membrane patches. Pflugers Arch 391:85-100.

Harden TK, Boyer JL, Brown HA, Cooper CL, Jeffs RA, Martin, MW (1990) Biochemical properties of a $P_{2 Y}$-purinergic receptor. Ann NY Acad Sci 603:256-266.

Hatten ME, Fishell G, Stitt TN, Mason CA (1990) Astroglia as a scaffold for development of the CNS. Neurosciences 2:455-465.

Hill DT, Berggren PO, Boynton AL (1987) Heparin inhibits inositol trisphosphate induced calcium release in permeabilized rat liver cells. Biochem Biophys Res Commun 149:879-901.

Illes P, Nörenberg W (1993) Neuronal ATP receptors and their mechanism of action. Trends Pharmacol Sci 14:50-54.

Inoue K, Nakazawa K, Ohara-Imaizumi M, Obama T, Fujimori K, Takanaka A (1991) Selective and competetive antagonism by suramin of ATP-stimulated catecholamine secretion from $\mathrm{PC} 12$ phaeochromocytoma cells. Br J Pharmacol 102:581-584.

Kalthof B, Bechem M, Flocke K, Pott L, Schramm M (1993) Kinetics of ATP-induced $\mathrm{Ca}^{2+}$ transients in cultured pig aortic smooth muscle cells depend on ATP concentration and $\mathrm{Ca}^{2+}$ stores. J Physiol (Lond) 466:245-262.

Kano M, Rexhausen U, Dreessen J, Konnerth A (1992) Synaptic excitation produces a long-lasting rebound potentiation of inhibitory synaptic signals in cerebellar Purkinje cells. Nature 356:601-604

Kastritsis CHC, McCarthy KD (1993) Oligodendroglial lineage cells express neuroligand receptors. Glia 8:106-113.

Kettenmann H, Banati R, Walz W (1993) Electrophysiological behavior of microglia. Glia 7:93-101.

Kimelberg HK (1988) Glial cell receptors. New York: Raven

Kirischuk S, Scherer J, Kettenmann H, Verkhratsky A (1995) Activation of $\mathrm{P}_{2}$ purinoreceptors triggers $\mathrm{Ca}^{2+}$ release from $\mathrm{InsP}_{3}$-sensitive internal stores in mammalian oligodendrocytes. J Physiol (Lond) 483.1:41-57.

Kraig RT, Nicholson C (1978) Extracellular ionic variations during spreading depression. Neuroscience 3:1045-1059.

Lytton J, Westlin M, Hanley MR (1991) Thapsigargin inhibits the sarcoplasmic or endoplasmic reticulum Ca-ATPase family of calcium pums. Biol Chem 266:17067-17071.

Magowski NS, Walz W (1992) Ionic dependence of a $P_{2}$-purinoreceptor mediated depolarization of cultured astrocytes. J Neurosci Res 32: $530-538$.

Maire JC, Medilanski J, Straub RW (1982) Uptake of adenosine and release of adenine derivates in mammalian non-myelinated nerve fobers at rest and during activity. J Physiol (Lond) 323:589-602.

Minta A, Kao J, Tsien R (1989) Fluorescent indicators for cytosolic calcium based on rhodamine and fluorescein chromophores. J Biol Chem 264:8171-8182.

Müller T, Möller T, Berger T, Schnitzer J, Kettenmann H (1992) Calcium entry through kainate receptors and resulting potassium-channel blockade in Bergmann glial cells. Science 256:1563-1566. 
Müller T, Grosche I, Ohlemeyer C, Kettenmann H (1993) NMDAactivated currents in Bergmann glial cells. Neuroreport 4:671-674.

Müller T, Fritschy JM, Grosche J, Pratt GD, Möhler H, Kettenmann H (1994) Developmental regulation of voltagc-gated $\mathrm{K}^{+}$channels and $\mathrm{GABA}_{\mathrm{A}}$ receptor expression in Bergmann glial cells. J Neurosci 14: $2503-2514$.

O'Connor SE, Dainty IA, Leff P (1991) Further subclassification of ATP receptors based on agonist studies. Trends Pharmacol Sci 12 : 137-141.

Penner R, Fasolato C, Hoth M (1993) Calcium influx and its control by calcium release. Curr Opin Neurobiol 3:368-374

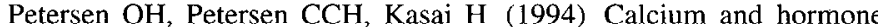
action. Annu Rev Physiol 56:297-319.

Reimer WJ, Dixon SJ (1992) Extracellular nucleotides elevate $\left[\mathrm{Ca}^{2+}\right]$ in rat ostcoblastic cells by intcrcation with two receptor subtypes. Am J Physiol 263:C1040-C1048.

Richardson A, Taylor CW (1993) Effects of $\mathrm{Ca}^{2+}$ chelators on purified inositol 1,4,5-trisphosphate $\left(\mathrm{InsP}_{3}\right.$ ) receptors and $\mathrm{InsP}_{3}$-stimulated $\mathrm{Ca}^{2+}$ mobilization. J Biol Chem 268:11528-11533.
Salter MW, Hicks JL (1994) ATP-evoked increases in intracellular calcium in neurons and glial from the dorsal spinal cord. J Neurosci 14 $1563-1575$

Salter MW, De Konink Y, Henry JL (1993) Physiological roles for adenosine and ATP in synaptic transmission in the spinal dorsal horn. Prog Neurobiol 41:125-156.

Sawynok J, Downie JW, Reid AR, Cahill CM, White TD (1993) ATP release from dorsal spinal cord synaptosomes: characterization and neuronal origin. Brain Res 610:32-38.

Stone TW (1981) Physiological roles for adenosine and adenosine 5'triphosphate in the nervous system. Neuroscience 6:523-555.

Thastrup O (1990) Role of $\mathrm{Ca}^{2+}$-ATPases in regulation of cellular $\mathrm{Ca}^{2+}$ signalling, as studied with the selective microsomal $\mathrm{Ca}^{2+}$-ATPase inhibitor, thapsigargin. Agents Actions 29:9-15.

Walz W, Ilschner S, Ohlemeyer C, Banati R, Kettenmann H (1993) Extracellular A'TP activates a cation conductance and $\mathrm{K}^{+}$conductance in cultured microglial cells from mouse brain. J Neurosci 13:44034411.

Yu H, Ferrier J (1993) ATP induces an intracellular calcium pulse in osteoclasts. Biochem Biophys Res Commun 191:357-363. 